\title{
DAMPAK SOSIAL DAN PSIKOSOSIAL BAGI PENGUNGSI PASCA KONFLIK ANTARA SUNNI - SYIAH DI SAMPANG MADURA
}

\author{
Hazim \\ Education Care Community Jawa Timur
}

\begin{abstract}
Horizontal conflicts involving religious issues in Indonesia is still very dominant. The conflict between Sunni and Shia in Sampang Madura is the one case of the large impact. the case that occurred on August 26, 2012 has caused in one person died, dozens of people were injured, dozens of homes burned and hundreds of Shias were evacuated. This phenomenon has encouraged me to analyze the psychosocial and social impacts experienced by refugees. This research was focused to the background of horizontal conflict that occured between Sunni and Shia in Sampang, Madura; Conflict resolution efforts, the psychosocial and social impacts for Refugees Shi'ites in Rusun Puspa Agro Jemundo Sidoarjo? This study has used descriptive qualitative. The subject of the research was focused on Shiites who has been evacuating in Jemundo Sidoarjo. The results of this study showed that the conflict was influenced by many factors: ideological, family conflict, economic motive, and local politics. The conflict resolution has been conducted in several stages: stages of de-escalation; stages of humanitarian intervention and political negotiations; stages of problem solving approach; and the last, Peace of building stages; which includes the transition, reconciliation, and consolidation. The social impacts of refugees in Jemundo Sidoarjo were Loss of residence; Loss of livelihood sources; created a dependency with others; For children, they can not access a proper education as well as have been experiencing disorders of psychological development; The refugees have not have basic freedoms: Limited access to health social services; Moreover, there will be impoverishment in the long term.
\end{abstract}

Key words: Psychosocialand social impact, conflict, Refugees

\begin{abstract}
ABSTRAK
Konflik horizontal yang melibatkan agama di Indonesia hingga kini masih sangat dominan. Konflik antara Suni dan Syiah di Sampang Madura adalah salah satu contoh kasus yang menimbulkan dampak besar. Kasus yang terjadi pada 26 Agustus 2012 ini telah mengakibatkan 1 orang meninggal dunia, puluhan orang luka-luka, puluhan rumah terbakar dan ratusan warga Syiah dievakuasi.Fenomena ini mendorong peneliti untukmenganalisis dampak sosial dan psikososial yang dialami bagi para pengungsi. Penelitian ini difokuskan pada:Latar-belakang konflik, upaya resolusi konflik serta dampak sosial dan psikososial yang ditimbulkan pasca konflik bagi warga yang mengungsi di Rusun Puspa Agro Desa Jemundo Sidoarjo. Metode yang digunakan adalah deskriptif kualitatif. Subjek penelitian difokuskan pada Kelompok Syiah yang mengungsi di Rumah Susun Jemundo Sidoarjo. Hasil dari penelitian menunjukkan bahwa konflik ini dipengaruhi oleh banyak faktor: ideologis, keluarga, Motif ekonomi, Politik lokal. Upaya penyelesaian konflik dilakukan dalam beberapa tahapan: tahap de-eskalasi konflik; tahap intervensi kemanusiaan dan negosiasi politik; tahap Problem solving approach. Dan terakhir, tahap Peace building; yang meliputi transisi, rekonsiliasi, dan konsolidasi. Adapun dampak sosialnya adalah Kehilangan tempat tinggal; Kehilangan sumber mata pencaharian; Tercipta ketergantungan dengan pihak lain; Bagi anak-anak, terganggunya pendidikan anakanak dalam pengungsian dan mengalami gangguan perkembangan psikologis;
\end{abstract}


terpasung kebebasan: Terbatasnya akses layanan sosial kesehatan; dan dalam jangka panjang adalah terjadi pemiskinan yang akan dialami oleh para pengungsi.

Kata Kunci: Dampak Sosial dan Psikossial, konflik, Pengungsi

\section{PENDAHULUAN}

Konflik horizontal yang melibatkan agama di Indonesia hingga kini masih sangat dominan, baik yang bersifat antar agama maupun antar kelompok dan golongan sesama agama. Padahal dampaknya bisa sangat buruk dan mengerikan bagi kehidupan kemanusiaan. Menurut Martin, "social conflict involving religion is greatly feared as a result of the extreme violence against peoples and cultures perpetrated in the name of religion. (Bouma, 2001).

Era Reformasidi Indonesia pada 1998 merupakan tonggak kebebasan masyarakat sipil, termasuk kebebasan mengekpresikan gerakan keagamaan. Bagi warga Muslim, Menurut Julia Howell, kebebasan keagamaan diekspresikan dalam dua bentuk yang berbeda, pertama, secara communalist, tindakan komunal diwujudkan dengan membentuk partai politik untuk mendorong terwujudnya Negara Islam Indonesia. Dan kedua, relatively autonomousmodes of religiosity yang ditandai dengan bermunculannya kelompok-kelompok Islam baru. (Howell, 2011), seperti Hizbut Tahrir Indonesia (HTI), Front Pembela Islam (FPI), Majelis Mujahidin Indonesia, dan lain-lain. Masing-masing kelompok perbedaan satusama lain baik dari sisi pemikiran, platform dan karakteristik gerakannya. Perbedaan perilaku keagamaan sangat ditentukan oleh sudut pandangnya terhadap masalah disekitar.

Menjadi masalah ketika sebagian dari mereka mengklaim sebagai yang paling benar dan menolak kebenaran dari kelompok lain. (Hasan, 2011). Perbedaan Wordview yang dibarengi dengan keterbatasan pengetahuan serta kesenjangan dalam beberapa aspek kehidupan sosial, seperti politik dan ekonomi antar satu dengan kelompok lainnya telah menjadi pemicu terjadinya konflik horizontal (Hasan, 2011). Wujud konfliknya bisa bermacam-macam. Mulai dari yang hanya bersifat konflik simbol hingga melibatkan fisik. Dampaknyajuga bervariasi, dari tingkat yang ringan hingga sangat parah. (Lay, 2009).

Yayasan Denny JA mencatat bahwa sejak Reformasi 1998 hingga Desember 2012 telah terjadi 2,398 kasus konflik. Sebanyak 65\% dilatarbelakangi oleh perbedaan agama atau perbedaan pemahaman keagamaan (Bangka 2012). Sebuah angka yang cukup fantastis karena terjadi di suatu Negara yang tidak sedang berkonflik.

Konflik antara Syiah dan anti Syiah di Sampang Madura yang telah berlangsung cukup lama dan berulangulang, hingga akhirnya mencapai klimaks pada 26 Agustus 2012 menjadi salah satu kasus konflik antar kelompok agama yang menyedot perhatian dalam beberapa tahun terakhir ini. Pasalnya, konflik tersebut telah mengakibatkan korban yang cukup parah. Terdiri dari satu orang tewas dan sejumlah orang lainnya luka parah, serta puluhan rumah terbakar (Gatra, 2012). Selain itu, telah mengakibatkan sejumlah warga syiah diungsikan ke Rumah Susun di komplek pasar Puspa Agro, Desa Jemundo Sidoarjo. Hingga kini, pengungsi Syiahsebanyak 235 jiwa, terdiri atas orang dewasa dan anak-anak (Tempo.co, 2014).

Keputusan untuk mengungsikan kelompok Syiah mungkin bisa menjadi solusi untuk menghindari terjadinya 
konflik susulan antara kedua kelompok tersebut. Tetapi posisinya di pengungsian telah dan akan menimbulkan masalah sosial baru yang sangat komplek bagi pengungsi. Mereka tidak mendapatkan hak untuk hidup dengan bebas dan menjalankan aktifitas sosial maupun ekonominya secara wajar. Modal sosial dan modal ekonomi mereka adalah di Sampang, bukan di Jemundo, Sidoarjo, apalagi berada di pengungsian yang tentunya penuh keterbatasan.

Dinamikan sosial terkait dengan konflik yang terjadi antara Syiah dan non syiah ini penting untuk dilakukan kajiansecara mendalam berkaitan akar masalah timbulnya konflik, upaya resolusi serta dampak sosial bagi para pengungsi yang hingga kini masih berada di komplek Rumah Susun Desa Jemundo Sidoarjo. Untuk itu, diperlukan sejumlah kajian teoritis agar bisa mengurai persoalan tersebut.

Secara etimologis, konflik berasal dan akar kata bahasa latin,yang berarti "bersama", dan figere,yang berarti "penyerangan". Dalam kamus, konflik ada kata-kata seperti "perkelahian", "perlawanan", dan penolakan keras mengenai kepentingan ataugagasan. Dalam bahasa Arab, konflik biasa diterjemahkan dengan kata niza' yang berarti pertentangan atau perselisihan. Pengertian terebut hampir sama dengan pemaknaan dalam bahasa Indonesia, yakni konflik didefinisikan sebagai percekcokan, perselisihan, atau pertentangan. Dalam istilah sosiologi, konflik adalah proses pencapaiantujuan dengan cara melemahkan pihak lawantanpa memerhatikannorma dan nilai yangberlaku.

Adapun secara terminologis, para pakar memberikan definisiyang beragam, di antaranya; Pickering yang mengatakan bahwa konflik tidak lebih dari adanya beberapa pilihan yang saling bersaing atau tidak selaras. Fisher mendefinisikan konflik sebagai hubungan antara dua pihak atau lebih (individu atau konflik) yang memiliki atau merasa memiliki sasaran-sasaran yang tidak sejalan. Sedangkan Roxane mendefinisikan konflik sebagai dua atau lebih reaksiyang bertentangan terhadap suatu peristiwa atau perbedaan antara dua individu, adanya saling permusuhan antara kelompok, atauadanya suatu masalah yang harus diselesaikan. Dari tiga definisi di atas, dapat disimpulkan bahwa yang dimaksud konflik adalah adanya kesenjangan antara harapan dan kenyataan yang membawa kepada ketidakharmonisan terhadap individu ataupun kelompok.

Lebih jauh, Fisher (2007) mengilustrasikan konflik melalui diagram berikut: 
Figure 2.1.

Goals and Behavior

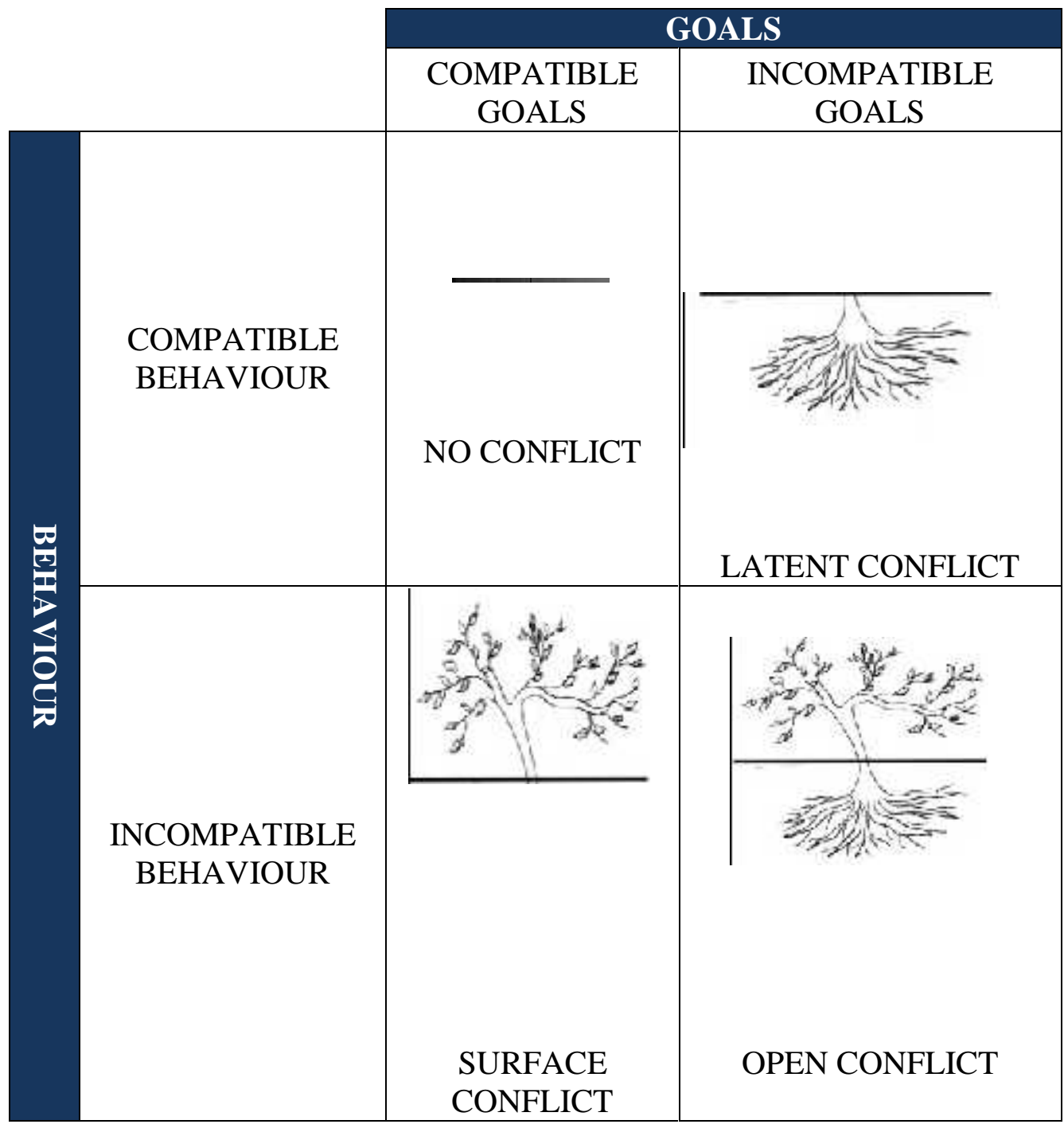

Gambar di atas menunjukan hubungan antara tujuan dan perilaku serta dampaknya berkaitan dari konflik:

- No conflict: A common perception may be that the box on the top left, no conflict is preferable. However, any peaceful group or society, if it is to endure, must be lively and dynamic, incorporating conflicts of behavior and goals and addressing them creatively.
- Latent conflict is below the surface and, as already suggested may need to be brought in to the open before it can be effectively addressed.

- Surface conflict has shallow or no root and may be only misunderstanding of goals that can be addressed by means of improved communication.

- Open conflict is both, deep-rooted and very visible. and may require actions that adress both the root 
causes and the visible effects. (Fisher 2007)

Berdasarkan tipologi yang diformulasikan oleh Fisher, konflik antara Suni dan Syiah di Sampang yang meledak pada 26 Agustus 2014 dapat dikategorikan sebagai konflik terbuka (open conflict). Eskalasi konflik yang meningkat setelah terjadi perbedaan prinsip atau tujuan dan masing-masing pihak dan tidak bisa menjaga sikap untuk melakukan tindakan prenventif. Akibatnya konflik terbuka tak dapat dihindarkan.

Konflik sosial bisa terjadi dalam beberapa bentuk. Bouma membagi konflik Agama ke dalam tiga kategori: pertama, konflik antara dua kelompok agama yang memiliki kekuatan hampir berimbang untuk memperebutkan sejumlah sumber daya dan sesuatu yang dipandang penting dalam hidup, seperti: pekerjaan, tanah, makanan atau kekuatan politik.Kedua, konflik yang terjadi terhadap kelompok minoritas yang bisa terjadi ketika diantara mereka memiliki sejarah diperlakukan secara diskriminatif, diusik kenyamanannya atau karena sering difitnah baikoleh pimpinan maupun anggota kelompok masyarakat setempat. Masyarakat, dengan berbagai alasan, tidak bersedia memberikan ruang bagi kelompok minoritas tersebut untuk tinggal bersama masyarakat pada umumnya. Ketiga, konflik yang terjadi ketika Pemerintah bertindak represif terhadap suatu kelompok agama atau masyarakat tertentu. (Bouma 2001). Dalam konteks konflik Suni dan Syiah di Sampang, dapat dikategorikan konflik yang kedua. Konflik yang terjadi antara kelompok Suni sebagai kekuatan mayoritas dengan kelompok Syiah yang merupakan kelompok minoritas.

a. Resolusi konflik.

Secara empirik, menurut Andi Widjayanto yang dikutip oleh Syafuan
(2008) resolusi konflik dapat dilakukan dalam empat tahapan. Tahap pertama adalah de-eskalasi konflik. Tahap ini, konflik yang terjadi masih diwarnai dengan pertikaian. Upaya yang yang dilakukan masih berurusan dengan kondisi yang mengarah pada konflik fisik. Sehingga proses resolusinya terpaksa harus melibatkan militer untuk memulai (entry point) proses resolusi konflik.

Tahap kedua, Intervensi kemanusiaan dan negosiasi politik. Ketika de-eskalasi sudah terjadi, maka tahap intervensi kemanusiaan bisa dilakukan bersamaan dengan negosiasi antar elit politik untuk meredam ketegangan. Pada fase ini, kental orientasi politik dengan tujuan mencari kesepakatan politik antara aktor konflik.

Tahap ketiga, Problem solving approach. Fase ini diarahkan untuk menciptakan suatu situasi kondusif bagi pihak-pihak antagonis untuk melakukan trasnformasi suatu konflik yang spesifik ke arah resolusi. Secara empirik, terdapat empat komponen utama dalam proses problem solving. Pertama, masing-masing mengakui legitimasi pihak lain untuk melakukan inisiatif komunikasi tingkat awal. Kedua, masing-masing pihak memberikan informasi yang benar kepada pihak lain tentang kompleksitas konflik, yang meliputi sebab-sebab konflik, trauma-trauma yang timbul ketika konflik, dan kendala-kendala sosial yang akan menghambat fleksibilitas mereka dalam melakukan proses resolusi konflik. Ketiga, kedua belah pihak menemukan pola interaksi yang diinginkan untuk mengkomunikasikan signal-signal perdamaian. Keempat adalah problem solving workshop yang berupaya untuk menyediakan suasana kondisi bagi 
pihak-pihak terkait untuk melakukan proses resolusi konflik.

Tahap Keempat, Peace building; yang meliputi tahap transisi, rekonsiliasi, konsolidasi. Transisi merupakan tahap yang memerlukan waktu cukup lama karena menyangkut orientasi kultural dan struktural. Tahap selanjutnya adalah Rekonsiliasi yang bisa dilakukan jika potensi konflik terdalam yang dialami oleh komunitas adalah rapuhnya kohesi sosial karena beragam struktural yang terjadi dalam dinamika sejarah komunitas tersebut. Langkah terakhir dari proses peacebuilding adalah tahap konsolidasi. Dalam tahapkonsolidasi ini, semboyan utama yang ingin ditegakkan adalah "Quo

Desiderat Pacem, Praeparet Pacem".

Semboyan ini mengharuskan aktoraktor yang relevan untuk terus menerus melakukan intervensi perdamaian terhadap struktur sosial dengan dua tujuan utama yaitu mencegah terulangnya lagi konflik yang melibatkan kekerasan bersenjata serta mengkonstruksikan proses perdamaian langgeng yang dapat dijalankan sendiri oleh pihak-pihak yang bertikai.

Selain empat tahapan di atas, ada beberapa macam usaha yang bisa dilakukan untuk mewujudkan perdamaian, yaitu:

1. True graduated and reciprocated iniciatives (TGRI)

Teori yang dikembangkan
oleh Charles Osgood ini
menjelaskan pentingnya melakukan
konsesi lateral untuk menjalin
perdamaian. Dalam hal ini bisa
dilakukan dengan cara: 1)
mengeluarkan pernyataan umum
mengenai keinginan untuk
mengurangi konflik. Hal ini harus
mendapatkan dukungan publik serta

tanggung jawab yang sama bagi kelompok lain untuk lebih bekerjasama. 2) Menyuarakan keingin perdamaian meskipun tidak ada keingin serupa dari kelompok lain. 3) ketika kelompok lain ingin bekerjasama, maka harus direspon dengan cepat. 4) tetap menjaga kemampuan untuk bertindak keras untuk menjaga terjadinya eksploitasi dan penyerangan kembali dari kelompok lain.

2. Mediasi.

Untuk melaksanakan upaya resolusi konflik diperlukan strategi mediasi. Dalam rangka itu, maka mediasi harus dibangun atas landasan filosofis kerahasiaan (confidentiality), kerelawanan (voluntariness), pemberdayaan (empowerment), kenetralan (neutrality), solusi yang unik (unique solution).

3. Negosiasi.

Agar negosiasi dapat berjalan dengan baik, Muhsin Jamil dalam Mundiroh (2014) membagi beberapa tahap. Pertama, menfokuskan pada interest. Artinya mencari kepentingan yang sama bukan kepentingan dalam posisi sendirisendiri. Kedua, berusaha mencari opsi tentang substansi interest obyektif yang dapat diterima oleh kedua belah pihak. Ketiga, mengadakan evaluasi mempertimbangkan memilih interest mana yang dijadikan dan lebih bersifat praktis dapat dilaksanakan atau interest yang menguntungkan kedua belah pihak. Semua yang telah disepakati tercatat secara tertulis sebagai dokumen. Kelima, masingmasing pihak harus berkomitmen mematuhi kesepakatan yang telah dibuat. 


\section{Superordinate}

Pengenalan akan identitas superordinate cara yang umumnya dilakukan untuk mengatasi konflik antara kelompok. Ketika kelompok merasa bahwa mereka memiliki identitas yagn mirip maka rasa kepemilikan akan lebih besar dan tidak hanya terkait dengan kelompok mereka saja dan interaksi antar kelompok menjadi damai. (Mundiroh, 2014).

b. Dampak sosial pascakonflik bagi pengungsi.

$\begin{array}{ccc}\text { Relokasi } & \text { warga } & \text { Syiah ke } \\ \text { pengungsian } & \text { sebagai } & \text { upaya }\end{array}$
menghindari konflik sesungguhnya bukan tanpa menimbulkan masalah. Hal ini berakibat munculnya sejumlah masalah baru. Baik jangka pendek maupun jangka panjang.

United Nation Hight Commission for Refugees (UNHCR) menyebutkan bahwa pengungsi adalah orang yang meninggalkan tempat tinggalnya karena adanya unsur pemaksa seperti bencana alam berupa banjir, kekeringan, kebakaran, gunung meletus, tanah longsor, gelombang pasang air laut, tsunami, wabah penyakit dan peperangan. Tujuan orang mengungsi adalah untuk mencari tempat yang lebih aman demi keselamatan diri dan keluarga. Pengungsian bisa untuk sementara waktu ketika kondisi masih dalam bahaya dan dapat kembali ke tempat asal ketika keadaan sudah aman.

Meski demikian, mereka harus tetap terjamin hak asasi manusianya. Sebagaimana diatur dalam Deklarasi Universal Hak Asasi Manusia (DUHAM), Konvensi Internasional tentang Hak Ekonomi, Sosial dan Budaya, serta Konvensi Internasional tentang Hak Sipil dan Politik, adalah hak untuk memeluk agama, bebas dari perbudakan, bebas dari penyiksaan, meminta dan menerima perlindungan bantuan humaniter, kebebasan berpindah, rasa aman, pendidikan serta memperoleh informasi tentang keberadaan sanak saudara.

Dalam panduan pengungsi internal yang dikeluarkan oleh PBB Koordinator Urusan Kemanusiaan (OCHA), kebutuhan perlindungan bagi pengungsi meliputi lima prinsip yaitu:

1. Perlindungan umum meliputi hak memperoleh persamaan perlakuan hukum, kebebasan bersuara, perlindungan dari tindak diskriminasi, dan perlindungan khusus terutama untuk pengungsi anak anak, ibu hamil, perempuan kepala rumah tangga, lanjut usia serta orang cacat.

2. Perlindungan terhadap kemungkinan paksaan jadi pengungsi karena diskriminasi warna kulit, pembersihan etnis, agama dan politik.

3. Perlindungan selama masa pengungsian internal dari tindak genoside, pembunuhan, penculikan, penahanan, kekerasan, perampokan, penyanderaan, pemerkosaan, penghukuman kerja, penyiksaan, pencacatan, perbudakan, eksploitasi, pelecehan seksual, pengekangan gerak, pemaksaan ikut bertikai, penurunan martabat, moral dan mental. Pengungsi juga memperoleh hak untuk mengetahui tentang keberadaan keluarganya dan dipertemukan kembali, pemakaman yang layak apabila meninggal, memperoleh informasi tentang pilihan hidup yang lebih baik, pergi ke negara lain yang dipandang aman dan mencari suaka ke negara lain. 
4. Bantuan kemanusiaan berupa makanan, pakaian, kesehatan atau obat-obatan, pendidikan, hiburan, dan pelayanan administrasi kependudukan. Pemerintah dan pihak swasta harus menjamin kelancaran dan keamanan dalam menyalurkan bantuan kemanusiaan tersebut sehingga terhindar dari gangguan pihak-pihak yang tidak bertanggungjawab dan berbagai hambatan birokrasi.

5. Bantuan pemulangan, relokasi dan integrasi dengan masyarakat tempat pengungsi berada. (Gunanto Surjono, dkk. 2004: 7).

\section{METODE PENELITIAN}

Metode penelitian yang digunakan adalah deskriptifkualitatif. Metode ini dimaksudkan untuk memberikan gambaran secara sistematis, faktual dan akurat mengenai fakta-fakta, sifat-sifat serta hubungan antar fonomena yang diselidiki sehingga menghasilkan temuantemuan penting terkait dengan konflik yang terjadi antara Suni dan Syi'ah di sampang, khususnya mengenai dampaknya bagi pengungsi.

Lokasi penelitian difokuskan pada komplekpengungsian warga Syiah di Rumah Susun Puspa Agro,Jemundo, Taman Kabupaten Sidoarjo Jawa Timur. Untuk itu, jenis data yang diperlukan adalah data primer dan data skunder. Data primer yaitu data yang diperoleh peneliti secara mentah dari sumber data dan masih memerlukan analisis lebih lanjut (Subagyo, 2004;87). Jenis data primer dalam penelitian ini diperoleh secara langsung dari sumber data melalui interview, observasi, dan dokumentasi. Sedangkan datasekunder yaitu Jenis data yang diperoleh atau berasal dari bahanbahan kepustakaan. Data ini berupa dukumen, buku, majalah, jurnal, media cetak maupun media online, dan lain-lain yang berkaitan dengan permasalahan penelitian.

Teknik pengumpulan data yang digunakan terdiri dari; observasi, interview, dan studi dokumen adalah Interview, Observasi, dan studi dokumen. Secara garis besar metode observasi dapat dilakukan dengan dua cara: pertama, observasi dengan partisipan yaitu peneliti menjadi bagian dari kelompok yang diteliti. Kedua, observasi non partisipan, yaitu memposisikan peneliti sebagai orang di luar kelompok yang diteliti, kehadiran peneliti hanya sebagai pengamat kegiatan (Nasution, 1996, 107-108).

Dalam penelitian ini penulis menggunakan observasi non partisipan. Peneliti hanya mengamati kejadian di lokasi penelitian, peneliti tidak termasuk bagian dari obyek penelitian. Metode observasi ini digunakan untuk memperoleh data tentangsemua objek yang berkaitan dengan peristiwa konflik antara Kelompok Suni dan Syiah di sampang Madura serta kondisi yang terjadi di Pengungsian Desa Jemundo Sidoarjo. Obyek yang diobservasi antara lain adalah kondisi tempat tinggalnya di pengungsian, aktifitas saat di pengungsian dan pola interaksi sosialnya.

Interview adalah suatu kegiatan yang dilakukan guna mendapatkan informasi secara langsung dengan mengajukan pertanyaan-pertanyaan kepada responden atau informan (Abu Ahmadi, 1997, 83). Ditinjau dari pelaksanaannya interview dibedakan atas tiga macam yaitu: pertama, Interview bebas: pewawancara bebas menanyakan apa saja, tetapi juga mengingat data apa yang akan dikumpulkan. Interview bebas ini dilakukan dengan tidak membawa pedoman wawancara tentang apa yang ditanyakan. Kedua, Interview terpimpin, yaitu interview yang dilakukan oleh pewancara dengan membawa sederatan pertanyaan lengkap dan terperinci. Ketiga, 
Interview bebas terpimpin, yaitu kombinasi antara interview bebas dan interview terpimpin. (Arikunto, 132).Dalam hal ini, jenis interview yang digunakan peneliti adalah interview bebas terpimpin, dan instrumen yang digunakan dalam interview adalah pedoman wawancara. Adapun yang menjadi informan adalah perwakilan dari pihakpihak yang terlibat langsung dalam kasus ini, serta sejumlah warga Syi'ah yang mengungsi di Puspa Agro Jemundo.

Selain dua hal di atas, penggalian data juga menggunakan teknik studi dokumen. Teknik ini digunakan dalam mengkaji tentang berbagai media maupun dokumen yang memiliki keterkaitan baik langsung maupun tidak dengan topik penelitian. Di antaranya adalah bukubuku referensi utama bagi kelompok Suni maupun Syiah, dokumen-dokumen dari MUI, baik berkaitan dengan fatwa maupun lainnya. Dokumen-dokumen pemerintah yang berkaitan dengan persoalan penelitian. Serta sejumlah media yang mengulas mengenai kasus konflik antara Suni dan Syiah di Sampang Madura.

Teknik analisis data yang digunakan pada penelitian ini adalah analisis diskriptif kualitatif, karena pada hakikatnya data yang diperoleh dalam penelitian ini berupa rangkaian kata-kata atau paragraf yang dinyatakan dalam bentuk narasi yang bersifat deskripif mengenai peristiwa-peristiwa nyata dalam lokasi penelitian.

Teknik analisa ini dimaksudkan untuk bisa memberikan gambaran secara menyeluruh tentang dampak sosial konflik yang terjadi antara Suni dan Syiah serta mampu menggali berbagai upaya yang dilakukan oleh sejumlah pihak dalam rangka menanggulangi terjadinya konflik susulan. Untuk mengkaji data-data tersebut peneliti menggunakan pendekatan berfikir induktif, yaitu peneliti berangkat dari kasus-kasus yang bersifat khusus berdasarkan pengalaman nyata (ucapan atau perilaku subjek penelitian atau situasi lapangan penelitian), kemudian dirumuskan menjadi model, konsep, teori atau definisi yang bersifat umum. Induksi adalah proses dimana peneliti mengkumpulkan data dan kemudian mengembangkannya suatu teori dari data tersebut (Mulyana, 2001, 156- 157).

Langkah- langkah teknik analisis deskripif kualitatif dalam studi ini, peneliti berpijak kepada pendapat Miles, Hubermen dan Yin (Suprayogo,2001, 192-197).antara lain:

a. Pengumpulan data. Kegiatan analisis data selama pengumpulan data dimulai setelah peneliti memahami fonomenafonomena yang sedang diteliti dan setelah mengumpulkan data yang dapat dianalisis.

b. Reduksi data, yaitu proses pemilihan, pemusatan perhatian pada penyederhanaan, pengabstrakan, transformasi data kasar yang muncul dari catatan-catatan lapangan. Data yang diperoleh dari lapangan ditulis dalam bentuk uraian atau laporan terinci. Data dalam bentuk laporan tersebut perlu direduksi, dirangkum, dipilih hal-hal yang pokok, difokuskan pada hal-hal yang penting dan dicari tema atau polanya.

c. Display data, yaitu rangkaian kalimat yang disusun secara logis dan sistematis atau menyajikan sekumpulan informasi yang tersusun yang memberikan kemungkinan ketika dibaca akan mudah dipahami tentang berbagai hal yang terjadi dan memungkinkan peneliti untuk membuat suatu analisis atau tindakan lain berdasarkan pemahamannya tersebut.

d. Penarikan kesimpulan dan verifikasi, yaitu suatu upaya untuk mencari 
kesimpulan dari permasalahan yang diteliti. Dari data penelitian yang sudah dianalisis dapat diambil kesimpulan serta menverifikasi data tersebut dengan cara menelusuri kembali data yang telah diperoleh.

\section{HASIL DAN PEMBAHASAN}

a. Latar Belakang dan dinamika konflik

Konflik yang terjadiantara SunniSyiah di Sampang, Maduratelah berlangung sejak 2004. Meskipun bentuknya hanya letupan-letupan kecil yang kemudian mereda. Hanya saja tidak banyak yang menyadari bahwa konflik kecil tersebut menyimpan potensi konflik (latent conflict) yang jika ada pemicu lebih besar akan mengakibatkan konflik yang bersifat terbuka (Open conflict) seperti yang terjadi pada pada Ahad, 26 Agustus 2012. Akibat dari peristiwa tersebut,satu orang tewas, 45 titik pembakaran yang terdiri dari 80 rumah terbakar, serta 282 warga harus mengungsi. (Iklil). Hingga kini, (23 Januari 2015), masih terdapat sebanyak 180 jiwa yang mengungsi di Rumah Susun Puspa Agro Jemundo Sidoarjo.

Hasil kajian dari sejumlah
sumber menunjukkan, bahwa
latarbelakang adanya konflik ini sangat
komplek; Ideologi, Keluarga, ekonomi
serta Politik. Pertama, secara ideologis,
antara Sunni dan Syi'ah memiliki
riwayat konflik yang cukup panjang
yang diakibatkan oleh perbedaan cara
pandang mengenai status Ali bin Abi
Thalib. Oleh karena itu, kemunculan
Keputusan fatwa Majelis Ulama
Indonesia (MUI) Propinsi Jawa Timur
No. Kep-01/SKF-MUI/JTM/I/2012
yang menyatakan Syi'ah sebagai aliran
sesat juga menjadi variabel pemicu
terjadinya konflik horizontal di Karang
Gayam Omben Sampang. Selain itu,
juga disebabkan oleh adanya

pernyataan dari Pengurus Wilayah NU dan Ulama Badan Silaturrahmi Ulama Pesantren Madura yang menyatakan bahwa Syi'ah sebagai aliran sesat sehingga penganut harus dibaiat kembali ke Sunni. (Mundiroh. 2014).

Kedua, faktor keluarga turut memberikan andil terjadinya konflik. Sebagaimana dikemukakan oleh Mabes Polri, insiden Sampang memiliki indikasi konflik antar keluarga, yang melibatkan anak-anak mendiang Kiai Makmun, yang disebut-sebut telah menganut Syiah semenjak dia tertarik Imam besar Syiah Iran, Ayatullah Khomeini, di awal tahun 80-an.Salahsatu anak Kiai Makmun, Roisul Hukama (40 tahun) tersinggung dan marah, setelah gagal menyunting santri pesantren Misbahul Huda, yang mengajarkan Islam Syiah, milik kakaknya, Tajul Muluk (41 tahun). Sejak saat itu, Rois menyatakan keluar dari Syiah, dan rajin berkampanye menyatakan Syiah sebagai ajaran sesat.(Heyder Affan, 2013).

Ketiga, Persoalan ekonomi politik juga menjadi faktor pemicu terjadinya konflik sosial ini. Andy Irfan, Koordinator Kontras Surabaya mengatakan motif berlatar ekonomi politik diduga kuat berkaitan dengan kepentingan investasi migas di Madura. Beberapa bulan sebelum peristiwa pembakaran, sejumlah rumah di Dusun Nangkernang, Desa Karang Gayam, Kecamatan Omben, Sampang, disurvey oleh otoritas Migas pemerintah. Aktivitas eksplorasi migas di sana, juga membuka jalan baru yang melewati sawah warga. Kejanggalannya, kenapa bukan jalan desa yang dilebarkan dan diperbaiki. Malah menggunakan lahan lain. Patut diduga konflik ini sengaja diciptakan untuk mengusir sebagian warga yang tanahnya digunakan untuk eskplorasi dan eksploitasi migas. 
Selain itu, menurut informasi dari Iklil, (pengurus Syi'ah Sampang), ada dugaan bahwa pengusiran warga Syi' ah juga dilatar-belakangi adanya kehawatiran para Ulama yang anti Syiah akan kehilangan potensi ekonomi diakibatkan oleh ajaran Syi'ah yang menawarkan tentang tradisi Maulid Nabi Muhammmad SAW secara berkelompok dan pembiayaan ditanggung bersama dengan maksud untuk meringankan beban ekonomi warga. Dengan demikian dalam satu event bisa merepresentasikan untuk banyak orang maupun keluarga, otomatis alokasi transport untuk Kyai yang diundang juga hanya sekali. Padahal dalam tradisi lama di kampung tersebut, warga terbiasa menyelenggarakan kegiatan Maulid Nabi secara mandiri dari rumah ke rumahdan tentu Kyai bisa menghadiri event lebih banyak dan transport tentu lebih banyak lagi.(Eddy, 2012).

Motif lain yang juga bisa mendasari konflik ini adalah kontestasi politik lokal. Menurut Andy, konflik ini ditunggangi oleh kepentingan politisi-politisi lokal jelang pemilukada Sampang. Ketidakmampuan Pemerintah Kabupaten Sampang melindungi kaum minoritas dan membiarkan terjadinya konflik adalah lebih dikarenakan untuk menjaga lumbung-lumbung dukungan. (Eddy, 2012).Sumber lain mengatakan bahwa Bupati pernah melarang atau menolak keberadaan Syiah di Kabupaten Sampang. (Mundiroh. 2014). Sementara itu, menurut Ketua Komnas HAM, Ifdhal Kasim, bahwa kasus ini mencerminkan bentuk kegagalan pemerintah dalam memberikan perlindungan kepada warganya yang menganut kepercayaan Syiah. (Eddy, 2012).
Serangkaian eskalasi konflik yang terjadi hingga meledaknya pada tanggal 26 Agustus 2012 merupakan cerminan dari terjadinya pertemuan antara incompatible behavior dan incompatible goals(Fisher, 2007). Suni dan Syi'ah sudah jelas memiliki prinsip dan tujuan (goals) yang berbeda. Yang berarti memiliki potensi konflik yang tinggi. Sejak tahun 2004, latent conflict sudah membayangi di antara kedua kelompok tersebut. Ketika perilaku (behaviors) tidak terkontrol, sehingga memicu incompatible behaviors, maka yang terjadi adalah open conflict.

b. Upaya penyelesaian konflik.

Untuk melihat upaya penyelesaian konflik Suni dan Syiah di Sampang, tulisan ini membatasi pada kasus konflik yang terjadi 26 Agustus 2012 yang menimbulkan korban jiwa dan warga syiah diungsikan.

Sebagaimana pembagian tahapan resolusi konflik menurut Andi Widjayanto, maka tahap penyelesaian konflik antara Suni dan Syi'ah di Sampang Maduramelalui tahapan sebagai berikut:

1. Tahap de-eskalasi konflik.

Meledaknya konflik pada 26 Agustus 2012 bermula ketika sejumlah rombongan siswa dari komunitas Syiah yang akan kembali ke Bangil, Pasuruan setelah berlibur hari raya idul fitri. Saat hendak kembali itu, puluhan massa sudah menghadang dan mengancam akan membakar dan membunuhnya karena sebenarnya mereka tidak diizinkan untuk belajar ke Bangil. Aksi pun berlanjut dengan melakukan pembakaran sejumlah rumah warga Syiah. Aksi pembakaran mengakibatkan bentrok antara dua kelompok. Setelah 
membakar, ribuan massa dari kelompok Sunni mulai melakukan penyisiran dengan bergerombol di sekitar SDN Karang Gayang, Omben, Sampang yang diduga menjadi tempat persembunyian beberapa warga Syiah. (seruu.com. 2012). Untuk melakukan deeskalasi, beberapa pasukan bantuan mulai didatangkan. Satuan Peleton Brimob Pamekasan pun menjaga lokasi tersebut. Untuk menanggulangi konflik lebih besar, ratusan pengikut aliran Syiah, Minggu (26/08/2012) malam, di ungsikan dari kampung halamannya menuju GOR Indoor kota Sampang. (seruu.com. 2012).

2. Intervensi kemanusiaan dan negosiasi politik.

Untuk mengantisipasi kejadian bentrok semakin meluas, ratusan pengikut aliran Syiah, Minggu (26/08/2012) malam, diungsikan dari kampung halamannya menuju GOR kota Sampang. Gubernur Jawa Timur yang turun ke lokasi konflik langsung menginstruksikan kepada Bupati untuk memberikan tempat yang layak bagi semua pengungsi penganut aliran Syiah. Langkah selanjutnya, Pemerintah Propinsi Jawa Timur membentuk tim rekonsiliasi yang diketuai oleh Abu A'la (Rektor IAIN Sunan Ampel Surabaya). Tim ini bertugas untuk melakukan mediasi antara kedua belah pihak. Dengan target warga Syiah bisa kembali ke kampung halaman. Upaya yang dilakukan adalah dalam bentuk dialog yang melibatkan ulama Suni dan Syiah. Dari beberapa fasilitasi dialog ternyata belum menemukan hasil yang bisa disekapati. Kelompok Suni mensyaratkan agar Syiah bertobat, sedangkan Kelompok
Syiah tidak merasa bersalah sehingga tidak mau bertobat. karena belum ada kompromi yang bisa disepakati.(Kompas 2013).

3. Tahap ketiga, Problem solving approach.

Langkah problem solving sudah diupayakan kedua belah pihak melalui beberapa tahapan. Pada 23 September 2013, sebanyak 50 perwakilan warga Sampang mendatangi penampungan sementara jamaah Syiah Sampang di rumah susun Puspa Agro, Jemundo, Sidoarjo. Kedua belah pihak membuat Ikrar Damai untuk mewujudkan perdamaian di antara warga yang terlibat konflik kekerasan di wilayah tersebut. Perwakilan warga Suni-Sampang, Muhjaroh mengatakan, pihaknya akan terus mengajak warga untuk mewujudkan perdamaian di Sampang, yang dapat terwujud bila didukung semua pihak termasuk pemerintah.Sayangnya pertemuan ini tidak dihadiri oleh para tokoh masyarakat dan ulama Madura. (Kiblat. 2013) Tim yang telah menyepakati damai ini kemudian bertemu dengan Wantimpres bidang Hukum dan HAM, selanjutnya bertemu dengan Ketua MPR RI, untuk menyampaikan perkembangan rekonsiliasi Sampang yang meniscayakan faktor keamanan bagi pengungsi Syiah Sampang untuk kembali ke kampung halaman. Menanggapi hal itu, para ulama Madura di antaranya K.H Ali Karrar dan K.H Syafiuddin Wahid mensyaratkan dilakukan pembinaan untuk pengungsi di Ponpes Assiddiqiyyah asuhan K.H. Noer Iskandar S.Q. sebelum pembangunan perumahan warga Syiah Sampang. (Sampang, 2014). 
Selain itu, warga Sampang, yang dulunya terlibat berseberangan dengan Syiah, dalam beberapa bulan terakhir ini sudah inten berkomunikasi, bahkan menurut informasi dari Ust. Iklil, hampir setiap hari ada warga Sampang yang berkunjung dan silaturahmi dengan kelompok Syiah di Komplek Rusun Jemundo. Ini adalah perkembangan yang memberikan signal harapan baik untuk membangun perdamaian di bumi Karanggayam Sampang. Walaupun hingga saat ini, belum ada langkah konkrit yang mengarah pada pemulangan dan penyediaan fasilitas tinggal di Sampang.

\section{Tahap Keempat, Peace building;}

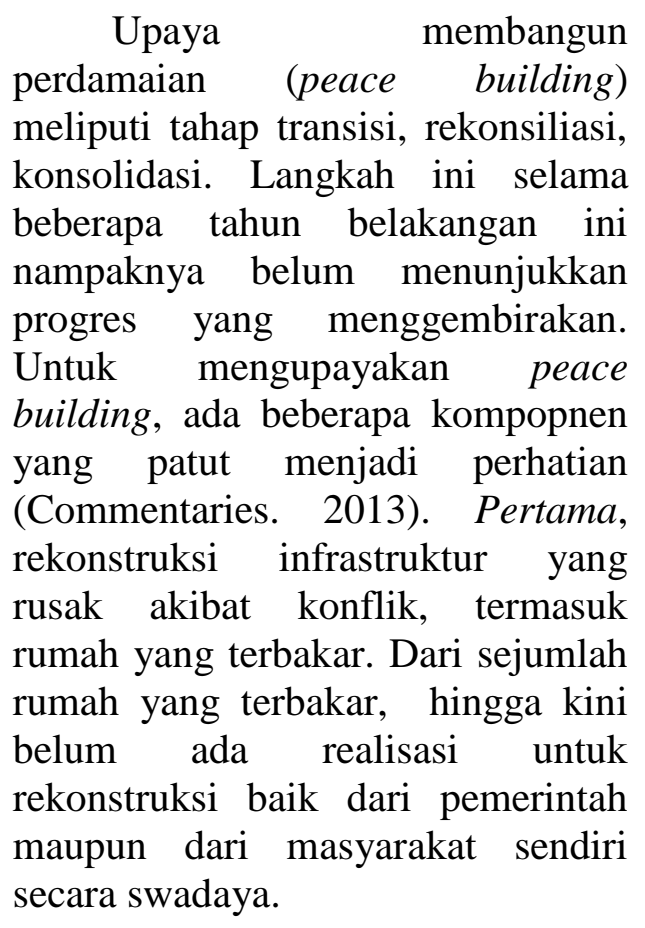

Kedua,

Repatriasi (pemulangan) adalah hal yang harus dilakukan. Meskipun hingga kini sebagian masyarakat Sampang masih keberatan dengan kepulangannya, tapi dari perspektif psikologis pengungsi, pemulangan adalah yang terbaik jika dibandingkan dengan relokasi, meskipun kondisinya lebih baik.
Untuk itu, Pemerintah harus mampu memberikan jaminan keamanan bagi para kelompok yang berkonflik.

Ketiga, harus ada upaya rekonsiliasi di antara kedua belah pihak. Dalam hal ini sangat penting adanya mediasi untuk terwujudnya kesepakatan damai dalam satu kawasan meskipun harus dibungkus dengan perbedaan pandangan. Keempat. Perlu dibangun pola komunikasi yang santun, yang tidak memicu pada ketersinggungan, sehingga kalaupun harus ada yang berbeda tetap bisa berjalan berdampingan dengan nirkekerasan. Langkah ini penting dilakukan sebagai bagian dari konsolidasi internal sesama warga.

Kelima, Aparat keamanan harus menjadi benteng terakhir penjaga perdamaian di lokasi yang rawan konflik tersebut. Polri harus berani mengerahkan kekuatan penuh yang terencana dan terukur - full force of law. Tidak cukup dengan tindakan persuasif saja. Juga diperlukan tindakan represif yang legitimate dari Polisi sebagai unsur negara yang diberi kewenangan menggunakan kekerasan atau ancaman penggunaan kekerasan.

c. Dampak Sosial dan Psikososial bagi pengungsi.

Konflik antara Suni dan Syiah telah menimbulkan sejumlah dampak sosial yang cukup besar. Kasus tersebut telah mengakibatkan sebanyak sekitar 180 jiwa mengungsi. Awalnya mereka diungsikan di GOR sampang, dan selanjutnya tanggal 20 Juni 2013 dipindahkan ke Rumah Susun Puspa Argo Jemundo Sidoarjo.

Keberadaannya di pengungsian tentu bukan merupakan solusi terbaik, tapi justru 
menimbulkan sejumlah dampak lanjutan yang harus dialami oleh mereka. Di antaranya adalah:

1. Kehilangan tempat tinggal untuk sementara waktu, bahkan tidak menutup kemungkinan bisa terjadi untuk seterusnya jika penduduk di wilayah konflik ini tidak tercipta kesepakatan yang memungkinkan kedua belah pihak bisa hidup berdampingan secara aman dan damai kembali. Hingga kini, berdasarkan informasi dari Iklil (Koordinator Pengungsi Syiah) sebanyak sekitar 80 rumah warga Syi' ah yang terbakar dari dua Desa juga belum ada pihak yang membantu merehab kembali. Sementara itu, dari Pemerintah belum memberikan kepastian alternatif solusi, apakah akan disiapkan tempat tinggal baru, atau dipulangkan, atau alternatif pemecahan yang lain.

2. Kehilangan sumber mata pencaharian. Sebelumnya, mayoritas mereka adalah petani yang sangat tergantung dengan lahan yang dimiliki di Desanya sebagai sumber ekonomi. Ketika mereka pindah dari desanya dan harus tinggal di pengungsian, mereka sudah tidak memungkinkan lagi menggarap lahannya di desa asal sementara ternaknya terpaksa harus dijual untuk menyelamatkan asetnya. Bahkan pada saat kejadian, sejumlah warga Syiah masih memiliki tanaman tembakau siap panen, tapi tidak sempat dipanen karena kondisi tidak memungkinkan. Untuk menambah penghasilan di pengungsian, sebagian aktifitas mata pencahariannya hanya mengandalkan sebagai buruh di pasar Puspa Agrowisata dengan penghasilan yang tidak menentu. Di antaranya ada yang bekerja sebagai pengupas kelapa dengan upah yang minim, itupun tidak setiap hari.

3. Tercipta ketergantungan dengan pihak lain. Untuk memenuhi kebutuhan hidupnya di pengungsian mereka mendapat disubsidi dari Pemerintah Propinsi Jawa Timur, berupa uang sebesar Rp. 709.000 perjiwa. Hanya saja pengungsi tidak tahu hingga kapan subsidi ini akan diberikan. Pada saat yang sama, pengungsidengan kondisi yang mengalami banyak keterbatasan--juga secara umum tidak memiliki rencana alternatif untuk mendapatkan income seandainya subsidi ini dihentikan. Kondisi ini menimbulkan ketidakpastian masa depan para pengungsi tersebut.

4. Terganggunya pendidikan anakanak dalam pengungsian. Saat ini, terdapat 1 anak SMA, 2 anak SMP, dan 50 anak duduk di bangku SD. Untuk anak usia SMP dan SMA difasilitasi sekolah di desa sekitar Pengungsian. Sementara yang SD difasilitasi sekolah di dalam komplek rumah Susun diperuntukkan khusus bagi anak pengungsi. Kondisinya pun jauh dari standart kualitas pendidikan. Karena keterbatasan dalam banyak aspek, Anak-anak SD dikelompokkan hanya dalam 2 ruang kelas. Satu ruang untuk anak kelas 1-3, dan satu ruang untuk anak kelas 4-6 SD. Tentu ini bukan hal yang mudah bagi guru untuk mendidik para siswa dalam satu kelas dengan tingkatan kemampuan dan usia yang beragam. Apalagi fasilitas yang 
dimiliki juga sangat terbatas. Jika kondisi ini terus berlangsung, maka akan sangat berpengaruh pada perkembangan psikologis anak, dan selanjutnya akan sangat berdampak pada rendahnya Sumber Daya Manusia bagi generasi mendatang yang sekarang mengungsi ini.

5. Bagi anak-anak, mengalami gangguan psikologis karena mereka berada dalam pusaran konflik secara berulang-ulang. Dampaknya anak-anak akan terbiasa dalam kondisi kekerasan, sehingga bukan tidak mungkin mereka kelak akan tumbuh menjadi anak yang bermental kasar dan frontal yang diakibatkan oleh akumulasi pengalaman kekerasan yang dialami.

6. Terpasung kebebasan dasar mereka. Dalam pengungsian, mereka menjadi kelompok yang teralienasi dari masyarakat. Padahal Manusia merupakan makhluk sosial yang membutuhkan interaksi satu sama lain dalam rangka pemenuhan kebutuhan hidupnya, baik yang bersifat fisik maupun psikologis. Keberadaannya di pengungsian, membuat mereka mengalami keterbatasan dalam hal berinteraksi. Mereka tidak memiliki kebebasan untuk berinteraksi dengan komunitas di luar pengungsi. Lebih-lebih pada anak yang memerlukan stimulan interaksi dari masyarakat lebih luas lebih dari sekedar komunitasnya di pengungsian untuk mendukung pengembangan dirinya, secara mental maupun sosial.

7. Terbatasnya akses layanan sosial kesehatan. Sejak keberadaan mereka di pengungsian Puspa
Agro, sudah terdapat sebanyak 5 Ibu yang melahirkan. Tragisnya, mereka melahirkan di tempat tinggalnya di pengungsian tanpa di dampingi oleh tenaga medis. Padahal melahirkan merupakan saat yang sangat beresiko dan sejumlah kemungkinan buruk bisa saja terjadi. Untungnya mereka bisa menjalani persalinan dengan selamat.

8. Dampak lain yang harus menjadi perhatian dalam jangka panjang adalah terjadi pemiskinan yang akan dialami oleh para pengungsi, karena mereka tidak memiliki kepastian penghasilan maupun kepemilikan aset. Aset lama yang berada di tempat tinggal asal tidak terkelola dengan baik, sementara di pengungsian tidak cukup memiliki kesempatan untuk memperoleh aset kehidupan yang baru. Sedangkan Subsidi dari Pemerintah hanya cukup untuk pemenuhan kebutuhan konsumtif sehari-hari.

\section{KESIMPULAN}

Berdasarkan pemaparan pada pembahasan di atas, yang bisa diambil sebagai kesimpulan adalah: Pertama, Konflik antara Sunni-Syiah di SampangMadura yang mencapai klimaks pada 26 Agustus 2012 dilatar belakangisejumlah faktor; 1) Secara ideologis, antara Sunni dan Syi'ah memiliki riwayat konflik yang cukup panjang yang diakibatkan oleh perbedaan cara pandang mengenai status Ali bin Abi Thalib. 2) Faktor konflik antar keluarga turut memberikan andil terjadinya konflik;3) Motif ekonomi menjadi faktor lainnya dari adanya konflik ini. Selain itu, 4) Politik lokal juga faktor lain yang memperkeruh konflik Suni dan Syi'ah di Sampang. 
Kedua, Kasus yang terjadi antara Suni dan Syiah sudah dilakukan sejumlah rangkaian upaya untuk melakukan resolusi konflik. Rangkaian yang sudah dilakukan adalah: tahap de-eskalasi konflik; tahap intervensi kemanusiaan dan negosiasi politik; tahap Problem solving approach. Dan keempat, tahap Peace building; yang meliputi transisi, rekonsiliasi, dan konsolidasi.

Ketiga, keputusan direlokasikannya warga Syiah ke pengungsian memberikan menimbulkan sejumlah dampak sosial bagi pengungsi: Kehilangan tempat tinggal untuk sementara waktu, bahkan tidak menutup kemungkinan bisa terjadi untuk seterusnya jika penduduk di wilayah konflik ini tidak tercipta kesepakatan yang memungkinkan kedua belah pihak bisa hidup berdampingan secara aman dan damai kembali; Kehilangan sumber mata pencaharian; Tercipta ketergantungan dengan pihak lain; Terganggunya pendidikan anak-anak dalam pengungsian; Bagi anak-anak, mengalami gangguan psikologis; terpasung kebebasan dasar pengungsi: Terbatasnya akses layanan sosial kesehatan; Selain itu, dalam jangka panjang adalah terjadi pemiskinan yang akan dialami oleh para pengungsi.

\section{DAFTAR PUSTAKA}

Bangka.tribunnews. 2012. 2.398 Kasus 'Buruk' Terjadi Pasca-reformasi, (23 December), http:// bangka. tribunnews.com/2012/12/23/2.398kasus-buruk-terjadi-pasca-reformasi, accd 17.4.2013
Bouma, Gary. 2001. Muslim Immigration, Religious Settlement and the Management of Religious Diversity: Comparing Australia and Italy, http://www.tasa.org.au /docs/conferences/ 2001_03/301101\%20Bouma.pdf. accd 5.4.2013

Cholid Nurboko dan Abu Ahmadi. 1997.Metodologi Penelitian, Jakarta: Bumi Aksara.

Commentaries, 2013. Strategi Bina-Damai di Sampang, (http://iis.fisipol.ugm.ac.id/...a\%20 Damai\%20di\%20Sampang.pdf), diakses pada 23 Desember 2014.

Dedy Mulyana. 2001. Metodologi Penelitian Kualitatif, Bandung: Remaja Rosdakarya.

Eddy Prastyo, Ada Apa di Balik Konflik Agama di Sampang?, Suara Suara.net, 2012 (http://www.suarasurabaya.net/foku s/34/2012/104057-Ada-Apa-diBalik-Konflik-Agama-di-Sampang), diakses pada 8 September 2014.

Fisher, Simon, et al. 2007. Working with conflict: skill and strategies for action, http://books.google.co.id/boo $\mathrm{ks}$ ?id=YCPEoKB1S54C\&pg=PT63 $\underline{\& \text { source }=g b s \_s e l e c t e d \_p a g e s \& c a d=}$ $\underline{3 \# \mathrm{v}=\text { onepage } \& \mathrm{q} \& \mathrm{f}=\mathrm{false}, \quad \text { accd }}$ 25.3.2013

Gatra, Syiah-suni membara, sampang berdarah, 27-8-2012.

http://www.gatra.com/nusantara/jaw a/16781-syiah-sunni-membarasampang-berdarah], akses pada $21 / 4 / 2014$

Hasan, Bakhtiar. 2011. Konflik Komunal Mengatas-namakan Agama di Indonesia: Analisis terhadap Konflik Ahmadiyah dalam Pemberitaan Media, 2005-2011, Kontekstualita, 26 (1): 71-115. 
Heyder Affan, 2013. Konflik keluarga, mazhab atau politik?, BBC

Indonesia, (http://www. bbc.co.uk/indonesia/ laporankhusus/2013/08/130731_laps us_syiah_sidoarjo_kilasbalik) diakses pada $12 / 10 / 2014$.

Howell, J.D. 2011. Closing the Gates: Anand Krishna and the Reassertion of Delimited Pluralism in Indonesia, www.cesnur.org/2011/dan-day.doc, accd 20.4.2013

Imam Suprayogo. 2001, Metodologi Penelitian Sosial-Agama, Bandung: Remaja Rosdakarya.

Iskandar. 2009, Metodologi Penelitian Pendidikan dan Sosial (Kuantitatif dan Kualitatif), Jakarta: Gaung Persada Press

Joko Subagyo. 2004, Metode Penelitian dalam Teori dan Praktek,Jakarta: Rineka Cipta.

Kartono, Kartini. 1983. Pathologi Sosial. Jakarta. Edisi Baru. CV. Rajawali Press.

Kiblat. 2013, Tanpa Dihadiri Ulama Madura, Syiah Sampang Deklarasi Kesepakatan Damai, (http://www.kiblat.net/2013/09/23/ta npa-dihadiri-ulama-madura-syiahsampang-deklarasi-kesepakatandamai/), diakses pada 21/11/2015.

Kompas, Pemerintah Bentuk Tim Rekonsiliasi Sampang, (http://nasional.kompas.com/read /2013/07/15/2312479/Pemerintah.B entuk.Tim.Rekonsiliasi.Sampang), diakses pada 23/11/2014.
Lay, Cornelis. 2009. Kekerasan Atas Nama Agama: Perspektif Politik,Jurnal Ilmu Sosial dan Ilmu Politik 13 (1):1-19.

Mery Ariansyah, Tinjauan Kiritis Terhadap Aliran Syi'ah di Sampang ", Sekolah Tinggi Keguruan dan Ilmu Pendidikan, (STIKIP) PGRI sumenep. (25 April 2013), (http://merymemei.blogspot. com/2013/04/makalah-tinjauankiritis-terhadap.html). diakses pada 10/10/2014.

Nasution, S. 1996, Metode Research, Jakarta: Bumi Aksara.

Seruu.com, 2012. Sampang Kembali Membara, Konflik Syiah vs Sunni Memakan Korban Jiwa, http://utama.seruu.com/read/2012/0 8/27/115424/sampang-kembalimembara-konflik-syiah-vs-sunnimemakan-korban-jiwa, diakses pada 21/11/2014.

Soebhan.Syafuan Rozi.2008. Cyberclash conflict resolution: panggilan mendamaikan dua bangsa serumpun, https://www.academia. edu/3442182/Teori_Sebumi_Solusi_ dan_resolusi_konflik Indonesia_Malaysia, diakses pada 10/11/2014.

Tempo.co, Dua Skenario agar Pengungsi Syiah Bisa Nyoblos, 02 April 2014, http://pemilu.tempo.co/read/news/20 14/04/02/269567406/Dua-Skenarioagar-Pengungsi-Syiah-BisaNyoblos] diakses pada 21/4/2014 